\title{
On the court jurisdiction in case of litigation between entrepreneurs
}

\author{
Cristina COJOCARU \\ The Bucharest University of Economic Studies, Bucharest, Romania \\ cristina.cojocaru@cig.ase.ro
}

\begin{abstract}
According to the Romanian legislation, the parties may agree in writing that the disputes concerning goods and other rights deriving from the non-performance of the contract be judged by other courts that, according to the law, would have territorial jurisdiction to hear the case, unless the competence of the court is exclusive. By decision no. 18/2016 the Romanian High Court of Cassation and Justice, through the competent division to judge the appeal in the interest of the law, decided that in matters of procedural substantive (material) jurisdiction of the specialized courts, the competence of the specialized courts is determined depending on the object or the nature of disputes such as those considered examples by art. 226 paragraph 1 of Law no. 71/2011 on the application of Law no. $287 / 2009$ on Civil Code. Considering also this decision, the article aims to analyze the practical implications of another recent decision of the Romanian supreme court, namely Decision no. 561/2018, on the competence of the specialized court in litigations between entrepreneurs and, without claiming to cover extensively the subject, to offer a view on the Romanian current legal framework, on the court jurisdiction and the notion of professional, underlining the freedom of entrepreneurs or professionals of choosing the relevant court.
\end{abstract}

Keywords: competence, jurisdiction, Romanian court, entrepreneurs, professional.

\section{Introduction}

A recent judgment of the Romanian High Court of Cassation and Justice (I.C.C.J.) [1] gives us the opportunity to make some considerations regarding the establishing of competence in the case of litigations arising from a contract concluded between professional traders in the exercise of their commercial activity.

Establishing the court jurisdiction - both material and territorial - is of particular importance throughout the settlement of the dispute, regardless of its nature. Thus, determining the competent court to hear the case results in essential consequences for the correct settlement and ultimately for the stability of the legal relationship between any party that may become a party to the litigation in a dispute.

For this reason, the law requires that prior to any decision or measure that may be taken in that case-law, the court invested with the trial of the case must first do the analysis and establishing of its competence. Without the correct establishing of court jurisdiction, any activity carried out will be null.

\section{Literature review and the legal framework Considerations on the court jurisdiction}

According to the specialized literature (Deleanu, 2013), the competence of the courts can be expressed in two ways, namely the space of the functional activity of a state body - hence we 
could say an objective meaning - but also in a subjective meaning - as an aptitude or power of that body to dispose of in the fulfillment of its mission.

Therefore, through jurisdictional competence, we can understand what a court of law can do, according to its function, its content and its scope, determined by law.

\section{The forms of jurisdiction}

The general rule of competence is to establish it by matter - rationae materiae competence and territorial competence - rationae loci competence.

In principle, in determining the competence by matter, it is considering the nature of the litigation and the value of the object of the dispute.

Undoubtedly the criterion of the nature of the dispute is essential in establishing the court jurisdiction and hence the naming of this competence as "material". For example, the judges judge applications for registration in civil status registers, those relating to the common wall, the right of passage, servitudes, etc., so the nature of the dispute is taken into account.

However, this criterion, by itself is not sufficient and another additional criterion is necessary, namely the value of the dispute. From an upward value the competence belongs to a higher court (starting with a value of 200,000 lei the jurisdiction belongs to the tribunal).

Vertically, the material competence is established by legal provisions.

Thus, besides the criterion of value, other criteria are also taken into account: cases not given in the jurisdiction of the higher court as the first instance, and that the court of control judges the actions against the decisions of the lower courts.

It is worth mentioning that some cases are given in the exclusive jurisdiction of some tribunals (county courts), such as the exclusive jurisdiction of the Bucharest Tribunal in cases strictly limited by law: withdrawal of compulsory licenses, registration of political parties or other cases strictly determined by law.

Moreover, an exclusive jurisdiction is also stipulated in case of specialized courts in areas such as cases concerning under-aged persons, administrative and fiscal litigation, labor and social security conflicts, the trade register, insolvency or other matters of this nature.

If this is the situation of the vertical jurisdiction, on horizontal - therefore the territorial jurisdiction, it is established in principle after the domicile or registered office of the party, unless the law provides otherwise.

The law also establishes a conventional or chosen competence, namely the parties may agree in writing or, in the case of disputes arose, by verbal statement before the court, that the proceedings relating to the goods and other rights that the parties can dispose of, be judged by other courts other than those which, according to the law, would have territorial jurisdiction to judge, unless the territorial jurisdiction is exclusive.

\section{The nature of the legal rules on competence}

Generally, the rules governing the jurisdiction of the courts of law are imperative legal norms, which determine the exclusive competence of certain courts to hear the cases attributed to them by law.

The rules governing material competence, but also exclusive territorial competence are such imperative legal norms. 
In some cases, however, territorial jurisdiction is governed by disposal norms, in situations when it is not exclusive.

The difference between competency rules is very important from the point of view of the sanction that intervenes in the case of its violation. The general rule ist that in the case of violation of an imperative norm - absolute lack of competence - the parties can not make any agreement on the court competence, can be invoked at any stage of the trial, all parties can invoke it, even the court of its own can do it, asking the parties about such a situation.

However, if it is a violation of a disposal norm in terms of competence, the situation is quite different. Thus, the parties may not ask for the court to decline the case, its invocation can only be made by the interested party and only by a pleading, or if the pleading is not mandatory, at the first hearing the latest.

\section{The principles stipulated by law which regulate the jurisdiction}

Firstly, the court competence is determined by law, only the law determines this competence.

Secondly, the jurisdiction is equal for all. In other words, these principles derive and are closely connected with the principle of equal rights of citizens and free access to justice, constitutional principles stipulated in art. 16 and 21 of the Romanian Constitution.

Another principle is that no court may delegate jurisdiction. According to art. 126 of the Constitution, the justice is done through the courts. Another principle is that the court only exercises its activity in its territorial jurisdiction.

The courts have the fullness of competence, meaning that no other authority can carry out court activities. However, by law it is necessary to establish another competence, but then that activity is also carried out by virtue of the law.

Other principles laid down in the legislation are: the judge of the claim is also the judge of the case, accessory follows the principal, meaning that the legal nature of a good, for example, of a right or act, etc., which is considered to be the main one, determines the competence of the secondary one, the accessory of the principal, the competence belongs to the court in whose jurisdiction the domicile of the defendant is located and competence conflicts are still within the jurisdiction of the court system.

\section{The material jurisdiction of local courts}

As a rule, art. 94 from the new Civil procedural code, the local courts have a common competence, as courts of first instance, but also a competence of judicial control, in the case of appeals against the decisions of some bodies of the public administration with jurisdictional activity.

In the first instance, the local courts judge the claims having a valuable or invaluable in money object, like applications given in the jurisdiction of the court of guardianship or family, requests for records in the civil status records, requests for the administration of multi-story buildings, apartments or spaces in the exclusive property of different persons, requests for evacuation in real estate claims, requests regarding the common wall and joint groove, the distance of the constructions, the right of passing, the servitude or the property rights, the requests for borders, possessory claims, requests for obligations to do which are invaluable in money, legal division of any value, any other claims worth up to 200,000 lei. 
As the judicial control court, the local court solves the appeal against the decisions of the public administration authorities with judicial activity in the cases provided by the law.

Also, the judges are hearing other claims given by law in their jurisdiction. This is the case, for example, of solving complaints against contravention minutes.

The exclusive material jurisdiction of local courts

PICBE | 658

Sometimes, the special law establishes an exclusive material competency for some local courts, on the criterion of the character of certain requests or the quality of the parties in litigations.

For example, the local court of 1st district in Bucharest, judges the complaints concerning the lists of special voters from abroad, requests for annulment, amendment, correction of civil status acts submitted by a foreign citizen or a Roman citizen with the domicile abroad.

Likewise, the local court of the 5th district in Bucharest hears the reviews in case of taxes due for claims addressed to the Ministry of Justice, or the local courts of Galati and Constanta that judge the claims in maritime and river matters.

\section{The material jurisdiction of tribunals}

According to art. 95 of Civil procedure code, the tribunals judge at first instance, in appeal and in recourse (second appeal).

In the first instance, the tribunals judge claims not given by law in the jurisdiction of other courts. In other words, it is always necessary to check whether the claim submitted is not under the jurisdiction of another court.

In appeal, the tribunal, according to the same article of the civil procedure code, hears the appeals against the judgments pronounced by the judges in the first instance, regardless of whether they handed down a decision on the grounds (such as against the decisions by which the litigation is not solved).

Such judgments handed down in the first instance may be appealed only if the law does not expressly provide otherwise.

Decisions that cannot be appealed are identified either by the fact that the law declares them without appeal or because the law stipulated for them only the second appeal (recourse).

As the court of recourse (second appeal), the tribunal hears recourses in certain cases provided by the law - art. 95 paragraph 3 C.p.c. Thus, according to the law, the judgments that may not be subject to recourse, are only susceptible to appeals; on the contrary, the law stipulates that certain judgments may be subject only to recourse.

Under the jurisdiction of the tribunal as a court of recourse any other claims laid down by law under its jurisdiction and litigations on industrial designs, applications for adoption if the competent court cannot be established.

\section{The material jurisdiction of specialized tribunals}

The law provides that in some areas specialized tribunals can be established, which will only judge cases in the field. 
There are specific areas like cases with minors and family, cases of administrative and fiscal litigation, causes on labor conflicts and social insurance, trade register, insolvency, unfair competition, etc.

It is therefore about causes which by number but especially by their specificity require a special category of tribunals.

It is worth mentioning that these tribunals are not an intermediate category between local courts and tribunals, but they take over the activity of the tribunals in the areas in which they operate, and they are on the same level as the usual tribunals.

Thus, being of the same rank as the usual tribunals, the specialized tribunals will function as first instance courts primarily, because it is hard to believe that in appeal or recourse would judge requests against judgment given by any local court in their special areas of activity.

\section{The material jurisdiction of courts of appeal}

In the first instance, the courts of appeal judge the claims on administrative and fiscal litigations according to the special law, and as the judicial control court, settles regardless of their name, appeals against judgments of the authorities of public administration with jurisdictional activity.

Moreover, it judges in the first instance any claims given by law in their competence (e.g. conflicts of competence between two local courts within its jurisdiction but not within the jurisdiction of the same tribunal; the conflict between a local court and the tribunal, both of its range of activity; claims for relocation of the trial if the court is from its jurisdictions, etc.).

As appeal courts, the courts of appeal judge the appeals against the judgments handed down by tribunals in the first instance.

As recourse courts, the courts of appeal hear the cases stipulated by law - art. 96 para. 3 of the civil procedural code, i.e. the judgements handed down in appeal, without the right to appeal and other judgements that the law expressly qualifies them as being subject to recourse, even if they are not subject to appeal.

\section{The material jurisdiction of the High Court of Cassation and Justice}

The supreme Romanian court hears the recourses declared against the judgments of courts of appeal and other decisions in cases stipulated by the law.

Even more, this court hears the appeals in the interest of the law as well as requests for the purpose of giving a preliminary ruling on legal issues, but also any other requests given by law in its competence (requests for relocation of the trial when the courts are not in the jurisdiction of the same court of appeal, requests for objection to judges, claims when a court is prevented from working for a longer period due to exceptional causes, etc.).

\section{The territorial jurisdiction of courts}

To establish territorial competences - thus horizontally - the law turns to several criteria, namely, the defendant domicile, the defendant residence, the domicile or the residence of the plaintiff. 
The domicile, as the factual situation is easier to prove by any means of probation. Obviously, the easiest way to prove it is by the identity card but if there is any challenge, the court must establish this situation of the main domicile by any means of evidence.

After the claim has been made before the court, any change of the domicile does not result in the change of the jurisdiction of the court.

If the domicile is not known, or defendant does not have a domicile, the claim will be introduced to the defendant residence, which is therefore a secondary criterion in establishing territorial competencies.

The plaintiff's domicile or residence is a second alternative criterion, and it is applied when neither the domicile nor the defendant residence is known.

\section{The conventional or chosen jurisdiction of courts}

According to art. 126 from the civil procedural code, the parties may agree in writing, or in the case of disputes borne, also by verbal declaration before the court, that litigations relating to goods and other rights that they can dispose of, be judged by other courts than those which would be territorial competent according to the law, if this competence is not exclusive.

If we are in the situation of a plurality of defendants, the claim can be submitted to the relevant court against any of the defendants.

\section{The alternative territorial jurisdiction of courts}

For better administration of justice and sometimes also to protect the interests of the plaintiff, the law stipulates an alternative territorial competence.

According to art. 109-111 of civil procedural code, the request for a judgment may be also started against a legal person of private law at the place where it has a dismemberment without legal personality, for the obligations to be executed in that place or arose from acts concluded by the representative of that dismemberment.

Moreover, the claim against an entity without legal personality can be made to the competent court in accordance with the person to whom the members of that entity, by their understanding, have entrusted him with its management or administration.

Against the state, central or local authorities, the claims may also be introduced at the court in whose jurisdiction is the residence of the plaintiff or the defendant.

According to art. 113 of the civil procedural code, the claims may also be introduced at the court of residence of the plaintiff in matters regarding filiation, the court in whose jurisdiction is the domicile of the creditor-plaintiff in matters regarding life maintenance, including state allowances for children, the court from the place stipulated in the contract for the execution, either in part of the obligation in claims for execution, annulment, termination, rescission of a contract, the court of the place where the real estate is located in the event of renting, the court of the place of payment for obligations which arise from a bill of exchange or promissory note, the court of the consumer's domicile in claims relating to enforcement, the absolute nullity, cancellation, termination, rescission or unilateral termination of the contract concluded with a professional, or for the repair of damages to the consumer. 


\section{The professional under the Romanian Civil Code}

In Romania, a new civil code is in force starting with the $1^{\text {st }}$ of October 2011. This new law has repealed the former civil code, which was in force since 1864, inspired by the French civil code, as well as the commercial code, which was in force since 1887, being inspired by the Italian commercial code.

For the first time in our legislation, the notion of professional has a legal meaning. According to art. 3 of the new civil code, the professionals are "all those who exploit an enterprise". Furthermore, carrying out an enterprise, in the meaning of the civil code, is the systematic exercise of one or more persons, of an organized activity of producing, administration or sale of goods of services performance, having or not a patrimonial scope (Cristea, 2012).

Furthermore, according to the legal literature (Militaru, 2013), the subjects of the civil legal relationships are professional traders individuals or legal entities and professional nontraders. Thus, the professional traders individuals are the authorized individuals - sole traders, the individual enterprises and the family enterprises.

The professional traders legal entities are the companies, national companies, regies autonomous, cooperative companies, economic interest groups, European companies, European economic interest groups. The professional non-traders are the individuals who performs liberal professions, like the lawyers, pharmacists, doctors, expert accountants, authorized accountants, bailiffs, mediators, journalists, notary publics and authorized individuals which are not traders.

Consequently, other subjects of civil law that are not professionals are the individuals seen as consumers, legal entities of public law (the state, the territorial-administrative units, the Presidency, the Ministries, the Government, etc.) and the entities of private law, such as trade unions, employers' associations, etc.

Based on the definition from the Civil Code of the professional, it results that the difference between professional and other subject of law is the carrying out of an enterprise. Another distinction between these concepts refers to the fact that the other subjects of civil law have the capacity of consumers of the goods and services that results from the activity of the professional within its enterprise.

\section{Discussions}

In the above-mentioned case, the parties, the traders with registered offices in different counties, have established that any litigation between them should be judged by a local court in the county where the party undertaking the obligation has its registered office. However, the services were carried out in two other counties.

Initially, the claim was addressed to a tribunal in one of the counties in which the services in question were provided, but this court considered itself incompetent and declined the jurisdiction in favor of the tribunal in the county where the local court established by the parties, through their previous understanding, was located, on the grounds that the parties agreed that the litigation would be judged by that local court but was incompetent due to the high value of the litigation.

The court in whose favor the litigation was declined considered itself as being also incompetent with the reasoning that in this case, the object is of a commercial nature and the 
parties have the status of professional traders in the performance of their economic activity. As such the dispute falls within the competence of the specialized court. As such a specialized court does not operate in the stable county of the parties through their previous understanding, but operates in the county where the economic activities in question were conducted, the court declined the case to the specialized court in that county.

This latter tribunal considered itself as having no jurisdiction over the case and declined the case back to the tribunal in the county established by the parties, arguing that the contractual clause set up by the parties in favor of the local court in that particular county, a local court which is material incompetent court, and therefore jurisdiction would go to the material competent court, namely the superior court in that county, the tribunal.

The Romanian supreme court, i.e. High Court of Cassation and Justice, has been called upon to give a regulatory authority decision and has established that although the parties can establish the competent court, they have established a particular local court and have not used a general way of establishing the competent court, as in County X, and thus, that local court having no material competence -an absolute one - it results that only the litigations under the jurisdiction of that local court are covered by this agreement, not those under the tribunal jurisdiction.

Furthermore, because from the point of view of material competence, the jurisdiction belongs to the tribunal and considering that at the place where the services in question were rendered is also constituted the specialized tribunal, it results that this particular court has the jurisdiction over this litigation.

\section{Conclusion}

Establishing the jurisdiction of the court is a matter of the utmost importance, and otherwise it is the first issue that any court invested with the should analyze.

A misconception of the competencies of settlement leads most of the time to the nullity of both acts prepared by the incompetent court and the ineffectiveness of the eventual judgment handed down by that court.

In cases where competences belong to the specialized courts, they are not subordinate to ordinary courts, but have the same degree as the appropriate court, but only judge disputes that are given to them by law.

Consequently, this results in the fact that if the parties agree that any disputes may be judged by a certain court, their convention cannot derogate from the legal provisions concerning the material competence of the special Court - the case of commercial tribunals - where such special courts perform according to the law.

\section{References}

[1] I.C.C.J., Second Civil Division, Decision no. 561 of 27 February 2018.

Deleanu Ion (2013), Tratat de procedura civila, vol. I, Editie revazuta, completata si adaugata, Bucharest: Universul Juridic Publishing House, 592 and following.

Cristea Silvia Lucia (2012), Dreptul Afacerilor, Editia a treia revizuita si adaugita, Bucharest: Univeritara Publishing House, 80 and following.

Militaru Ioana Nely (2013), Dreptul afacerilor. Introducere in dreptul afacerilor. Raportul juridic de afaceri. Contractul. Bucharest: Universul Juridic Publishing House, 46 and following.

Law no. 134/2010 on the new civil procedural code, republished

Law no. $287 / 2009$ on the civil code. 